\title{
Impact of fish cage-culture on the community structure of zooplankton in a tropical reservoir
}

\author{
Juliana D. Dias, Érica M. Takahashi, Natália F. Santana \& Cláudia C. Bonecker
}

Programa de Pós Graduação em Ecologia de Ambientes Aquáticos Continentais, Nupélia, Universidade Estadual de Maringá, Av. Colombo, 5790, 87020-900 Maringá, PR, Brazil. (julianadeo@ hotmail.com)

\begin{abstract}
We investigated the impact of fish cage culture on the zooplankton community structure in a tropical reservoir. We hypothesized that community abundance is greater near cages and increases over time due to the increase in food availability. Samplings were performed near, upstream and downstream from net cages, and before and after net cage installation. The abundance of zooplankton increased 15 days after the experiment was set up, followed by a reduction and finally increased. Rotifer abundance showed significant differences among sites $(\mathrm{p}<0.05)$ and sampling periods $(\mathrm{p}<0.001)$. Significant differences were also observed in total zooplankton and cladoceran abundance $(\mathrm{p}<0.001)$. The spatial and temporal variation of the physical and chemical variables were indirectly correlated with the structure and dynamic of the zooplankton community, as they indicated the primary production in the environment. Our hypothesis was rejected, since the zooplankton was abundant at the reference site. Only rotifers showed higher abundance near cages, due to the influence of food availability. Community dynamics during the experiment was also correlated to food availability. Our results suggest an impact of fish farming on the zooplankton community.
\end{abstract}

KEYWORDS. Aquaculture, tilapia, environmental impact.

RESUMO. Impacto da piscicultura em tanques-rede na comunidade zooplanctônica em um reservatório tropical. O objetivo deste estudo foi investigar o impacto da piscicultura em tanques-rede sobre a estrutura da comunidade zooplanctônica em um reservatório tropical. Acredita-se que a abundância do zooplâncton é maior perto dos tanques-rede e aumenta ao longo do tempo devido ao aumento da disponibilidade de alimento. As coletas foram realizadas próximo aos tanques-rede, bem como a montante e a jusante dos mesmos, antes e após a instalação dos tanques. A abundância do zooplâncton aumentou 15 dias depois da instalação dos tanques, seguida por uma redução e posterior aumento no fim do experimento. A abundância dos rotíferos apresentou diferenças significativas entre os pontos $(\mathrm{p}<0,05)$ e períodos de amostragem $(\mathrm{p}<0,001)$. Diferenças significativas também foram observadas para a abundância do zooplâncton total e de cladóceros $(\mathrm{p}<0,001)$. A variação espacial e temporal das variáveis físicas e químicas apresentou uma relação indireta com a estrutura e dinâmica da comunidade zooplanctônica, pois essa variação indicou a produção primária no ambiente. A hipótese foi rejeitada, pois o zooplâncton foi mais abundante no ponto de controle. Apenas os rotíferos apresentaram maior abundância perto dos tanques, devido à influência da disponibilidade de alimento. No entanto, a dinâmica da comunidade durante o experimento também foi relacionada com a disponibilidade de alimento. Os resultados sugerem o impacto da piscicultura em tanques-rede na comunidade zooplanctônica.

PALAVRAS-CHAVE. Aquicultura, tilápia, impacto ambiental.

Fish cage-culture is an activity that has grown on a large scale in Brazil in recent years (ALVES \& BACCARIN, 2005) due to increased fishing productivity in Brazilian reservoirs and human population growth. Its use is an excellent alternative for fish production where the practice of conventional fish culture is not possible (SснміттоU, 1993). Nevertheless, this activity must be well-managed and monitored to avoid environmental degradation from water quality impact and exotic species introductions.

In fish cage-culture, the solid wastes (uneaten food, feces and mucus) and soluble wastes (phosphorus and nitrogen compounds) are dispersed directly into the water. Consequently, this activity constitutes an eutrophication risk (DEMIR et al., 2001).

These impacts influence the structure of the zooplankton community either through direct forces, such as by altering the physical and chemical characteristics of the water column in the reservoirs, or through indirect forces, starting with impacts caused by food resource availability and abundance of invertebrate and fish predators. According to Guo \& Li (2003), changes in plankton community structure initiated after the establishment of fish cage-culture were associated with the quantity of nutrients in the water. This increase in the quantity of nutrients caused an increase in phytoplankton biomass, resulting in a high biomass of herbivorous invertebrates (e.g., cladocerans).

Despite the ecological impact of fish cage-culture on the environment, few studies investigated that (DEMIR et al., 2001; JIWYAM \& CHAREONTESPRASIT, 2001; YIYONG $e t$ al., 2001; GuO \& Li, 2003; ABERY et al., 2005; AlVES \& BaCCARIN, 2005; HAKANSON, 2005; NEOFITOU \& Klaoudatos, 2008; Santos et al., 2009; Borges et al., 2010). This is probably related to a greater concern for food production than for the conservation of water resources. This concern about food production was clearly observed in Brazil in 2003 when the Brazilian government supported improved fish cage-culture practices in public waters.

Spatial and temporal variation in zooplankton abundance was investigated according to physical and chemical variables and food resource availability (bacteria, ciliates, heterotrophic flagellates and phytoplankton communities) following the establishment of fish cage-culture in a tropical reservoir. We hypothesized that zooplankton abundance is greater near cages and increases with time following cage establishment due to the increase in food availability. 


\section{MATERIAL AND METHODS}

Study area. The study was carried out in the lacustrine zone of a lateral arm of Rosana reservoir (Paranapanema river, Paraná river basin) in southern Brazil $\left(22^{\circ} 36{ }^{\prime} \mathrm{S}, 52^{\circ} 52^{\prime} \mathrm{W}\right.$; Fig. 1). This reservoir has an area of $220 \mathrm{~km}^{2}$, with total length of $116 \mathrm{~km}$, volume of $1,92010^{6}$ $\mathrm{km}^{3}$ and annual average flow of $1,203 \mathrm{~m}^{3} \mathrm{~s}^{-1}$. It shows a flooded area of 27,600 ha and theoretical residence time of water of 18.6 days (CESP, 1998).

The banks of the lateral arm are covered by grasses, predominantly sugar cane. Egeria najas, E. densa (Hydrocharitaceae) and Eichhornia azurea (Pontederiaceae) stands were distributed throughout the littoral region. The farm site was characterized as an

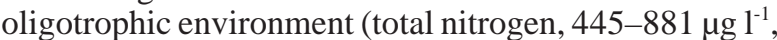
and total phosphorus, 9-25 $\mu \mathrm{g} \mathrm{l}^{-1}$ ). The maximum depth was $10 \mathrm{~m}$. Dissolved oxygen concentration varied between $6.27-8.81 \mathrm{mg} \mathrm{l}^{-1}$ and $\mathrm{pH}$ was neutral, while turbidity varied between 4.16-10.50 NTU during the study. The temperature varied between $20.3-28.5^{\circ} \mathrm{C}$ and the chlorophyll-a varied between $0.5-6.1 \mu \mathrm{g} \mathrm{l}^{-1}$. The main phytoplankton groups were Chlorophyceae, Cyanobacteria and Bacillariophyceae.

Field sampling. For the experiment, fifteen net cages were installed for the experimental cultivation of Nile tilapia (Oreochromis niloticus Linnaeus, 1758) in the lateral arm of the reservoir. The cages were transversally settled into three sets of five, with different densities of fish storage for each set $\left(50 \mathrm{~kg} \mathrm{~m}^{-3}\right.$ or $100 \mathrm{fish} \mathrm{m}^{-3}, 75 \mathrm{~kg} \mathrm{~m}^{-3}$ or 150 fish $\mathrm{m}^{-3}$, and $100 \mathrm{~kg} \mathrm{~m}^{-3}$ or 200 fish $\left.\mathrm{m}^{-3}\right)$. The cages had dimensions of $2 \times 2 \times 1.7 \mathrm{~m}$ and $6.0 \mathrm{~m}^{3}$ of volume. They were established at an approximate distance of $4.7 \mathrm{~km}$ from the reservoir. The fish were fed three times per day and the amount of food provided was adjusted according to temporal changes in biomass and growth of the fish in the cages ( $\leq 100 \mathrm{~g}$ wet weigth, $10 \%$ of extruded commercial food; $100-150 \mathrm{~g}, 5 \%$; $160-300 \mathrm{~g}, 3 \%$; 300-500 g, 1\%). The diet was composed by two extruded commercial foods (one with $32 \%$ of crude protein for the first 30 days and another with $28 \%$ of crude protein for the next 90 days).

The experimental design consisted of seven sampling stations at three different sites. Three sampling stations near farm site (S1, S2, S3), two sampling stations upstream the farm site (100 and $400 \mathrm{~m}$ distant from the cages, S6 and S7) and two sampling stations downstream the farm site (100 and $400 \mathrm{~m}$ distant from the cages, S4 and S5). The sampling stations upstream the farm site were considered control stations.

The first sampling (T0) was performed one week before the installation of fish cages (one near the farm site, two upstream and two downstream). These samples were considered as reference samples according to the temporal scale. After the beginning of the fish cageculture, seven samples were collected (three near the farm site, two downstream and two upstream). From all the sampling stations, three replicate samples were taken. These samples were collected over 120 days, between April and August 2006, and they were obtained from 15 days (T1), 30 days (T2), 60 days (T3), 90 days (T4) and 120 days (T5) after the beginning of fish cultivation.

Zooplankton was sampled at the subsurface of each sampling station using a motorized pump and plankton net $(68 \mathrm{~mm})$. For each sample, 200 liters of water were filtered through the net. The samples were preserved in formaldehyde (4\%) solution, buffered with calcium carbonate.

The bacteria, heterotrophic flagellates, ciliates and phytoplankton communities (food availability) were also sampled according to the same experimental design at subsurface using plastic bottles. Bacteria and flagellates samples were preserved using a solution compounded

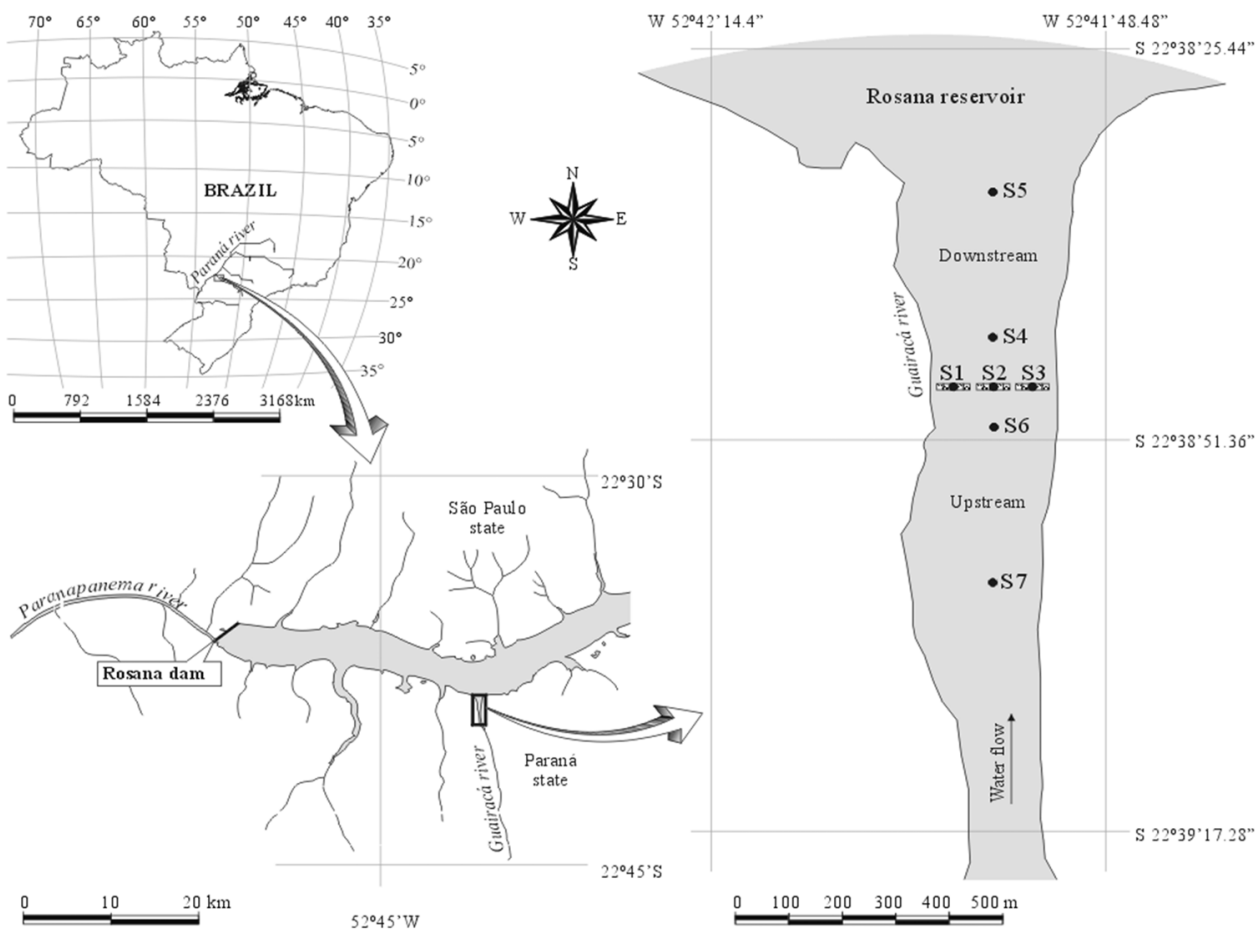

Figure 1. Study area with the location of sampling stations in Guairacá river in the lacustrine region of Rosana reservoir, southern Brazil 
by alkaline Lugol, formalin and sodium thiosulfate (SHERR \& SHERR, 1993). Ciliates samples were kept in the cooler until laboratorial procedure. Phytoplankton samples were preserved in $1 \%$ Lugol's solution.

Depth $(\mathrm{m})$, temperature $\left({ }^{\circ} \mathrm{C}\right)$, dissolved oxygen concentration ( $\mathrm{mg} \mathrm{l}^{-1}$ ) (YSI Model 55-12FT), conductivity $\left(\mu \mathrm{S} \mathrm{cm}^{-1}\right)$ (Digimed conductivimeter), $\mathrm{pH}$ (Digimed pHmeter), turbidity (NTU) (portable digital turbidimeter) and total alkalinity $\left(\mathrm{mEq} \mathrm{l}^{-1}\right)$ were measured at each sampling station (CARMOUZE, 1994). Water samples were collected by means of 5 liters van Dorn bottle and kept under refrigeration for posterior analysis in laboratory.

Laboratory analyses of nutrients and planktonic communities. In the laboratory, the concentrations of Nnitrate $\left(\mu \mathrm{g}{ }^{-1}\right)$ (GiNÉ et al., 1980), ammonia $\left(\mu \mathrm{g}^{-1}\right)$ and Pphosphate $\left(\mu \mathrm{g} \mathrm{l}^{-1}\right.$ ) (MACKereth et al., 1978) were measured from refrigerated samples.

Rotifer, cladoceran and copepod species were identified using an optical microscope and specialized literature. Total zooplankton abundance and the abundances of each group were estimated by three subsamples obtained with a Hensen-Stempell pipette $(2.5 \mathrm{ml})$, and at least 50 individuals from each group were counted in a SedgewickRafter chamber under an optical microscope according to BotTrell et al. (1976). Samples with low abundances were totally analyzed. All abundances were expressed as individuals per cubic meter $\left(\right.$ ind $\mathrm{m}^{-3}$ ).

For enumeration of bacteria $(0.2-2 \mu \mathrm{m})$ and flagellates $(2-20 \mu \mathrm{m})$, water samples were stained with DAPI (4,6'- diamidino-2-phenylindole: $0.001 \%$ final concentration). Concentration was by gentle vacuum filtration $(<15 \mathrm{~cm}$ of $\mathrm{Hg}$ ) on to $0.2 \mu \mathrm{m}$ (bacteria) and $0.8 \mathrm{im}$ (flagellates) Nucleopore polycarbonate black membranes. The filtered volume ranged between $0.1-1.5 \mathrm{ml}$ for bacteria and 5-15 ml for flagellate. Up to 400 bacteria or 50 fields and between 100-300 flagellates or 100 fields per sample, randomly distributed on the filter, were counted with epifluorescence microscope at $1000 \times$ magnification. Bacteria and flagellates abundances (cells $\mathrm{ml}^{-1}$ ) were measured by UV light (white-blue-fluorescence). Pigmented and heterotrophic flagellates were differentiated by filter set which provided blue excitation (resulting in red autofluorescence by pigmented and green fluorescence by heterotrophic organisms). Heterotrophic flagellates abundance was the difference between total flagellates abundance and pigmented flagellates.

Ciliates abundance (cells ${ }^{1-1}$ ) was determined in vivo through counting twenty aliquots of $25 \mathrm{ml}$ which were observed in optic microscopy, and the phytoplankton abundance (ind $\mathrm{ml}^{-1}$ ) was estimated by counting at random fields using inverted microscope, according to UTERMÖHL (1958).

Statistical analysis. To analyze the spatial and temporal ordination of the physical and chemical variables (depth, turbidity, $\mathrm{pH}$, total alkalinity, conductivity, temperature, dissolved oxygen, nitrate, ammonia and phosphate), a Principal Component Analysis (PCA) was applied. The significant axes were established according to the Broken-Stick criteria, proposed by JACKSON (1993). The data used were $\log$ transformed $(\log x+1)$, except for $\mathrm{pH}$. The PCA analysis was undertaken using PC-ORD software version 4.01 (MCCunE \& MEFFord, 1999).

The significance of mean variation of zooplankton abundance among different sampling stations and sampling periods was evaluated using a two way Analysis of Variance (ANOVA) (Sokal \& Rohlf, 1991), followed by a Tukey's test to identify significant differences $(p<0.05)$ among the means. The data were log transformed $(\log x+1)$ and the sites were grouped according to the following categories: upstream, farm site and downstream. These analyses were carried out using Statistica software version 7.1 (STATSOFT, 2005).

The influences of food availability (abundance of bacteria, heterotrophic flagellates, ciliates and phytoplankton) and the physical and chemical variables (PCA scores) on zooplankton abundance were evaluated using a Multiple Regression Analysis (SOKAL \& RoHlF, 1991). The data used were log transformed. This analysis was carried out using Statistica software version 7.1 (StATsoft, 2005).

\section{RESULTS}

Limnological variation. The PCA 1 and PCA 2 axes explained $58.26 \%$ of the spatial and temporal distribution of the physical and chemical variables (Tab. I). The PCA 1 axis $(36.08 \%)$ showed the negative influence of nitrogen, phosphorus and dissolved oxygen, and positive influence of $\mathrm{pH}$, turbidity, temperature and conductivity on the environmental conditions. The PCA 2 axis $(22.17 \%)$ was positively related to dissolved nitrogen and phosphorus, and negatively related to dissolved oxygen (Figs 2-4).

The PCA 1 axis scores showed clear temporal variation of the environmental condition observed in the experiment; the opposite could be observed in the spatial variation. In the T1 and T2 sampling periods, the values of $\mathrm{pH}$, temperature, turbidity and conductivity varied in contrast to the values of dissolved nitrogen, phosphorus and oxygen. Contrastingly, in the other sampling periods, we observed lower values of $\mathrm{pH}$, temperature, turbidity and conductivity and higher values of dissolved nitrogen, phosphorus and oxygen (Figs 2-4).

The PCA 2 axis scores also pointed to a clear temporal difference between $\mathrm{T} 0$ and the $\mathrm{T} 4$ and $\mathrm{T} 5$ sampling periods. Before the beginning of the experiment (T0), the environment presented high values of dissolved nitrogen and phosphorus and low values of dissolved oxygen. At the end of the experiment (T4 and T5), the environment also presented high values of these nutrients and high values of dissolved oxygen (Figs 2-4).

Abundance of bacteria, heterotrophic flagellates, ciliates and phytoplankton communities. An increase in the mean values of bacteria abundance was recorded 15 days before the net cages installation (T1), with a posterior decrease until the end of the experiment (T5). Heterotrophic flagellates presented greater abundance (T1) at the same time of the bacteria community and also decreased until the end. Otherwise, the ciliate abundance increased during the experiment and this community presented a peak at 90 days (T4) after the beginning of the experiment (Tab. I), see PEREIRA (2008).

The phytoplankton community showed an increased at 30 days (T2) after the net cages installation and an expressive decreased in the end of the experiment (T5) (Tab. I). The most abundant groups were Cyanobacteria and Cryptophyceae, see Borges et al. (2010). 
Table I. Spatial and temporal variation in environmental variables, bacteria, flagellates, ciliates and phytoplankton abundance registered in the Guairacá river, southern Brazil (Alka., alkalinity; Bact., bacteria; Cilia., ciliate; Cond., conductivity; DO, dissolved oxygen; Flag. flagellates; Phyt., phytoplankton; TDN, total dissolved nitrogen; TDP, total dissolved phosphorus; Turb., turbidity; T0, reference time; T1, 15 days; T2, 30 days; T3, 60 days; T4, 90 days; T5, 120 days following establishment of cage-culture; WT, water temperature).

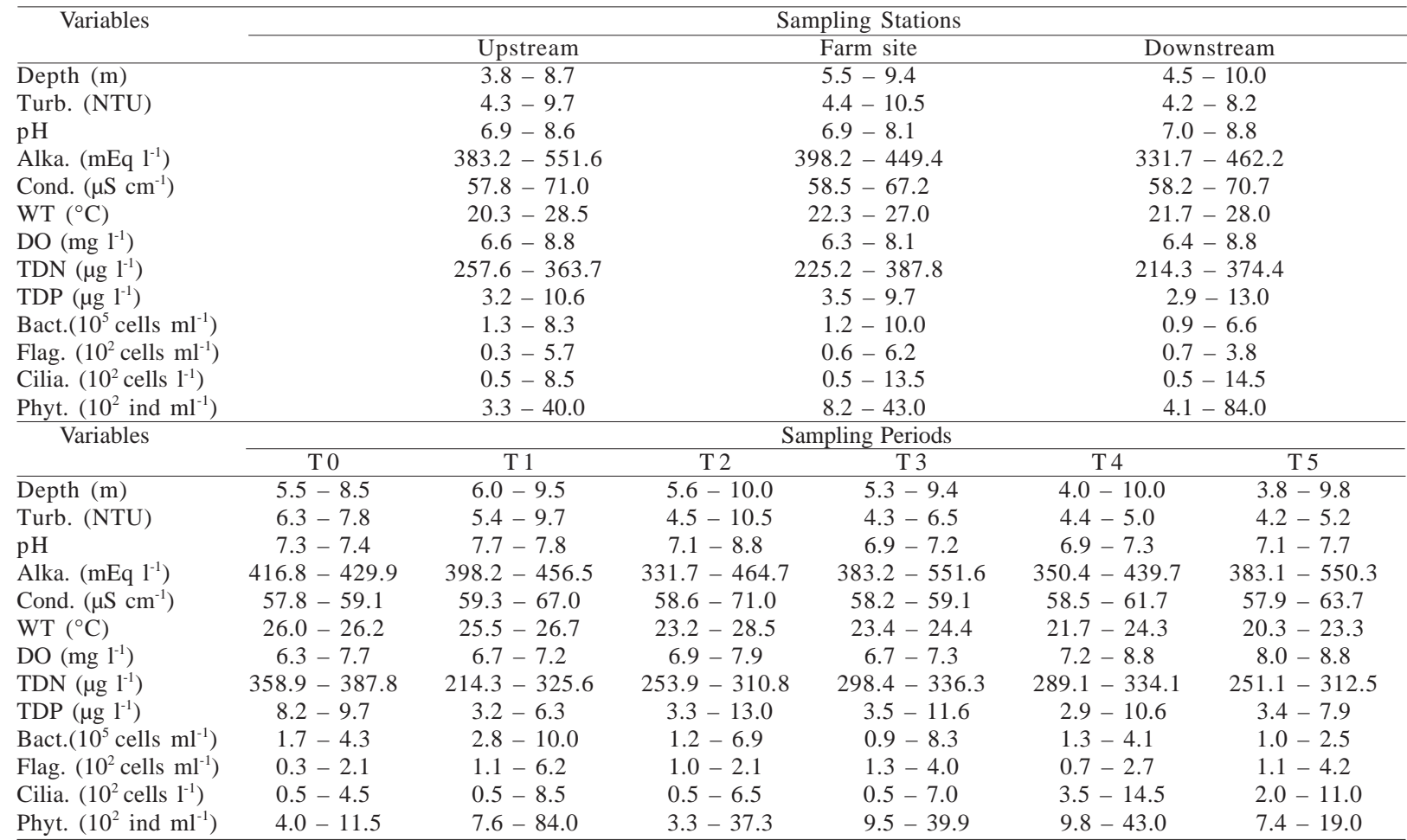
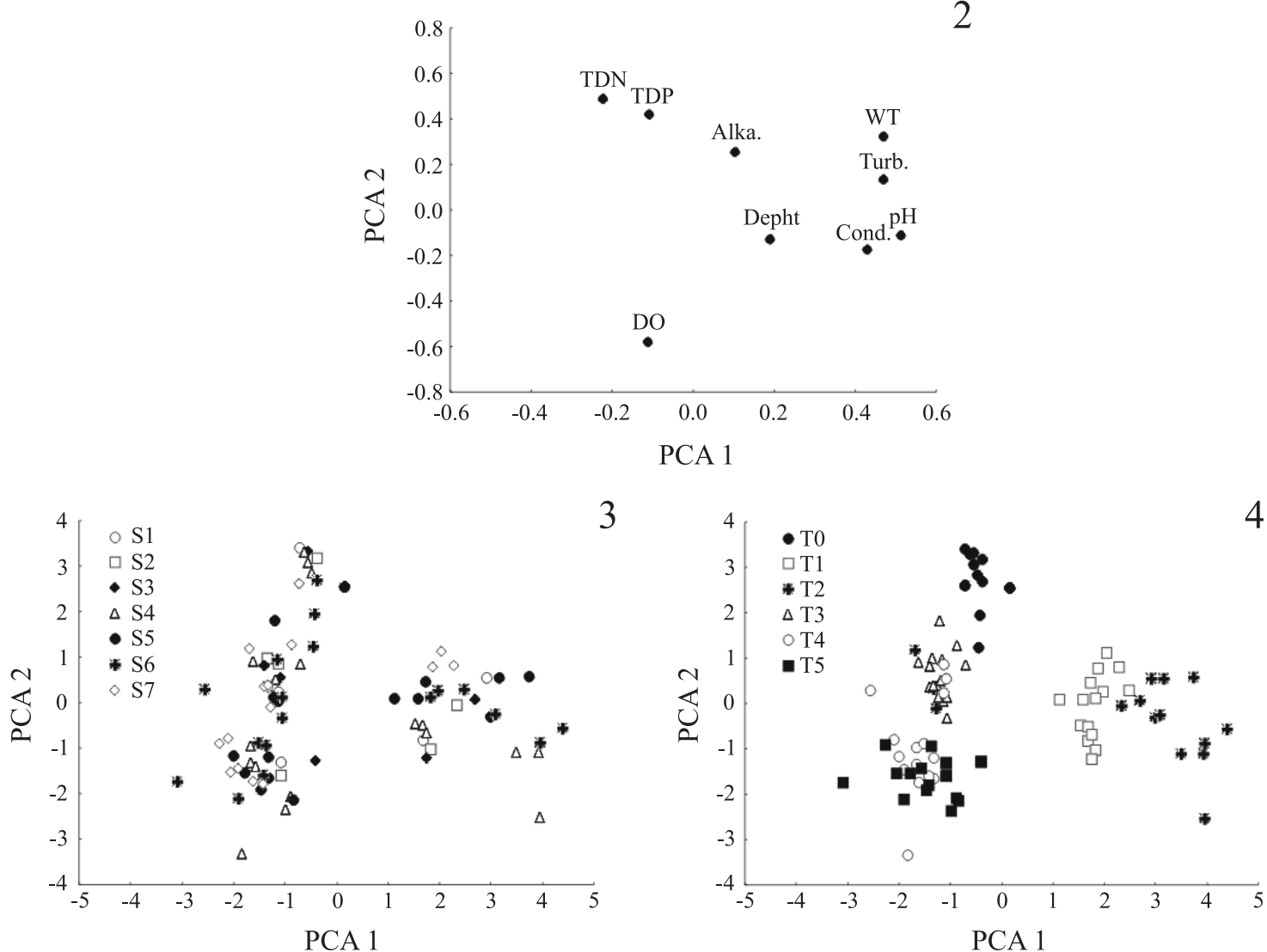

Figures 2-4. Dispersion scores from the Principal Component Analysis (PCA) in Guairacá river, Rosana reservoir, Paranapanema river, southern Brazil: 2, physical and chemical water variables; 3, spatial variation; 4, temporal variation (Alka., alkalinity; Cond., conductivity; DO, dissolved oxygen; TDN, total dissolved nitrogen; TDP, total dissolved phosphorus; Turb., turbidity; WT, water temperature). 
Community abundance. Zooplankton abundance ranged between 16,672 and 460,050 ind $\mathrm{m}^{-3}$ during the experiment, and rotifers were the most abundant group, followed by cladocerans, calanoid copepods and cyclopoid copepods. The most abundant zooplankton species are listed in table II .

The highest mean zooplankton abundance, and the greatest variation, was observed at S7 station (reference site). The lowest abundance was recorded at S3 station.
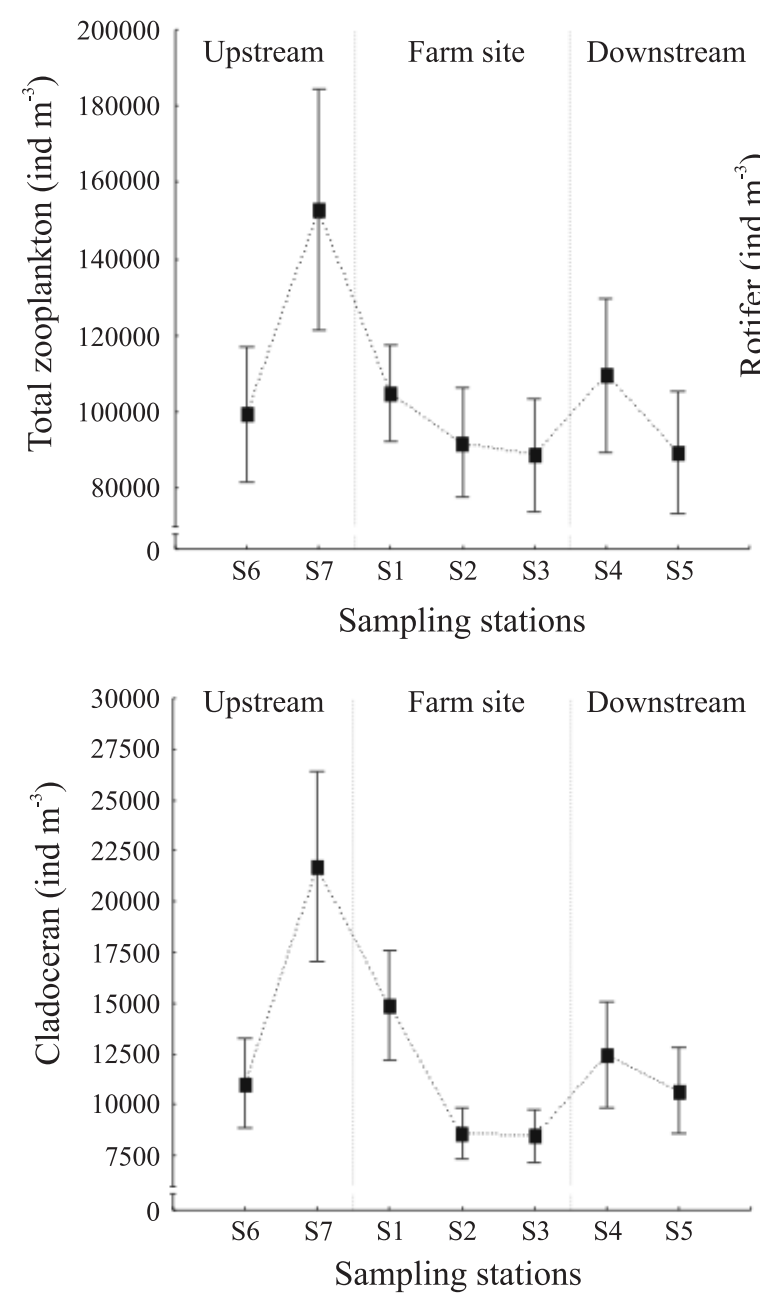

At the other sampling stations, the mean abundance values were similar. Cladoceran and copepod abundances were responsible for the spatial zooplankton abundance distribution in the experiment (Fig. 5).

The cladoceran abundance $\left(668-61,500\right.$ ind $\left.\mathrm{m}^{-3}\right)$ showed the highest mean values at the S7 station (reference site), where the greatest variation was also observed. Their lowest mean values were observed at the S2 and S3 stations. Calanoid $\left(5-28,500\right.$ ind $\left.\mathrm{m}^{-3}\right)$ and
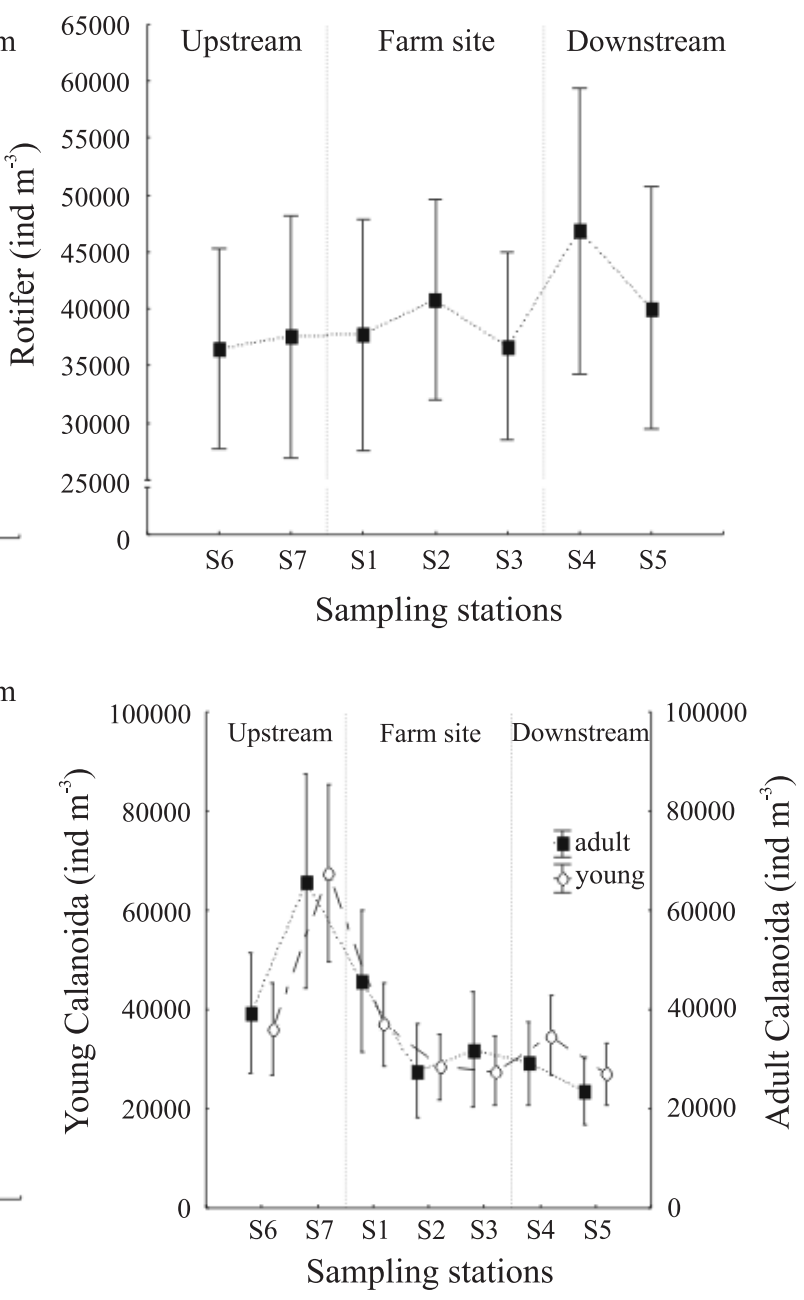

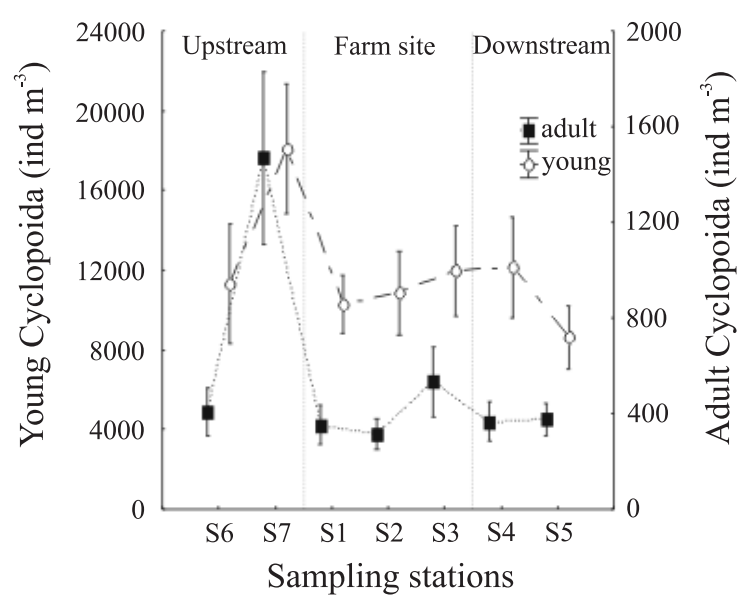

Figure 5. Abundance of total zooplankton and principal groups recorded in different sampling stations in Guairacá river, Rosana reservoir, Paranapanema river, southern Brazil (symbol, mean; bar, standard error). 
cyclopoid $\left(0-6,900\right.$ ind $\left.\mathrm{m}^{-3}\right)$ were also more abundant at the S7 station, where also observed the highest abundance variation of the latter copepods. The lowest abundance mean values of calanoid occurred at the S5 station, and cyclopoid, at S1 and S2 stations. The nauplii and copepodids (calanoid and cyclopoid) dominated the copepods abundance during the experiment. Finally, the rotifer abundance $\left(709-172,800\right.$ ind $\left.\mathrm{m}^{-3}\right)$ showed the highest mean values at S4, and the lowest at S6 station.
The variation in abundance for this group was greater within each station than among them (Fig. 5).

Temporal variation in total zooplankton abundance and zooplankton group abundance was also observed during the experiment. The abundances revealed an increase for the first 15 days (T1), and, afterwards, a reduction was observed. Other increases in zooplankton abundance were observed during T4 sampling period, mainly due to the rotifer contribution (Fig. 6).
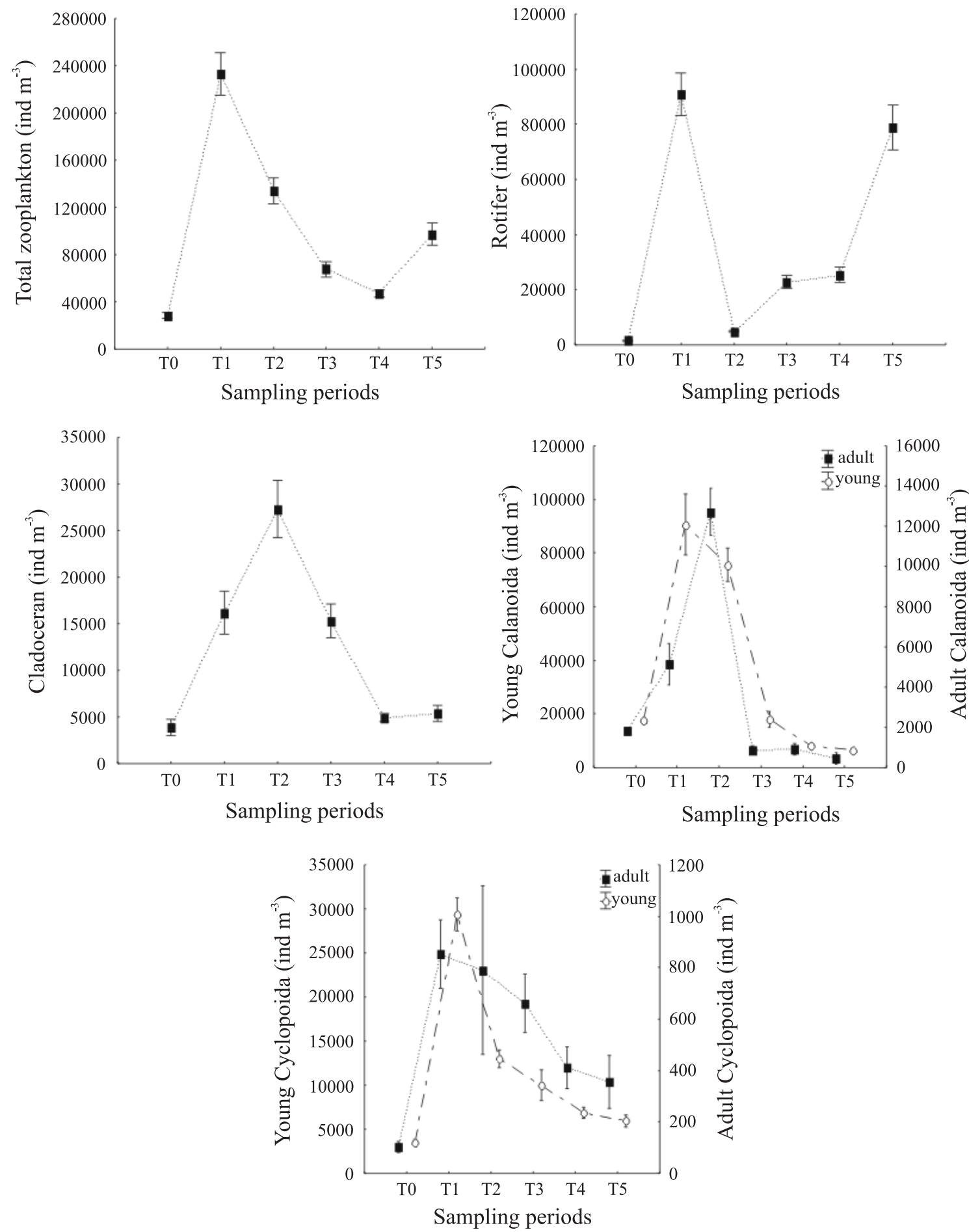

Figure 6. Abundance of total zooplankton and principal groups recorded in different sampling periods in Guairacá river, Rosana reservoir Paranapanema river, southern Brazil (symbol, mean; bar, standard error; T0, reference time; T1, 15 days; T2, 30 days; T3, 60 days; T4, 90 days; T5, 120 days following establishment of cage-culture). 
The rotifers presented high mean abundance during $\mathrm{T} 1$ and $\mathrm{T} 5$ sampling periods, while low values were verified during T0 (reference time) and T2 sampling periods. The cyclopoid copepods (young and adult stages), and the young calanoids also presented a peak of abundance during T1 sampling period, with a posterior and gradual reduction until the end of the experiment. Cladoceran and calanoid adults were abundant during $\mathrm{T} 2$ sampling period and after that gradually reduced (Fig. 6).

The ANOVA indicated significant differences $(p<0.05)$ among mean abundances of rotifers at different sites (upstream, farm site and downstream; d.f. $=2, F=4.37$, $\mathrm{p}=0.015$ ) and sampling periods (d.f. $=5, \mathrm{~F}=231.66, \mathrm{p}<0.001$ ). Furthermore, significant differences were also observed in total zooplankton abundance (d.f. $=5, \mathrm{~F}=83.74, \mathrm{p}<0.001$ ) and cladoceran abundance (d.f. $=5, F=36.20, p<0.001$ ). Other abundance results were not tested due to the fact that ANOVA assumptions were not reached.

The Tukey's test indicated that the mean abundance of rotifers was significantly different among the three sites of the experiment. Temporally, their mean abundance was similar between $\mathrm{T} 1$ and $\mathrm{T} 5$, and $\mathrm{T} 3$ and T4 sampling periods. Total zooplankton abundance indicated a significant variation among all sampling periods, with the exception of T2 and T5 sampling periods. The mean cladoceran abundance was similar among all sampling periods, with the exception of $\mathrm{T} 2$ sampling period (Fig. 7).
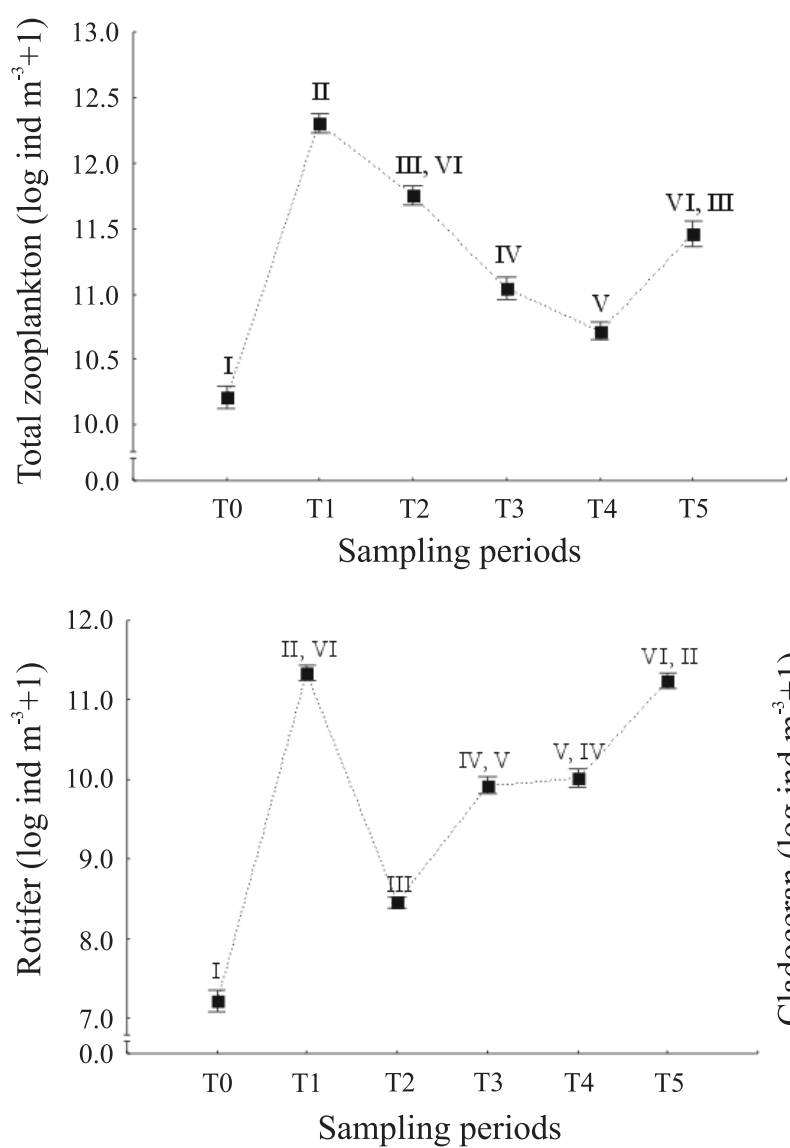

Multiple Linear Regression. The zooplankton abundance model (adjusted $\mathrm{R}^{2}=0.46$ ) suggested the influence of PCA 1, PCA 2 and phytoplankton abundance. Zooplankton abundance was positively correlated with PCA 1 and phytoplankton abundance, and negatively correlated with PCA 2. Among these variables, the PCA scores revealed the greatest contribution to the model (partial correlation for PCA $1=0.51$; PCA $2=-0.44$ ).

Table II. Most abundant species of rotifers, cladocerans and copepods registered in Guairacá river, Rosana reservoir, Paranapanema river, southern Brazil, with their respective abundance values (minimum and maximum/ind $\mathrm{m}^{-3}$ ).

\begin{tabular}{ll}
\hline \multicolumn{1}{c}{ Species } & Abundance \\
\hline Rotifers & $0-154,800$ \\
Synchaeta pectinata Ehrenberg, 1832 & $0-57,955$ \\
S. oblonga Ehrenberg, 1832 & $0-26,700$ \\
Conochilus coenobasis (Skorikov, 1914) & $0-12,183$ \\
Polyarthra dolichoptera Idelson, 1925 & $0-9,180$ \\
$\quad$ Conochilus unicornis Rousselet, 1892 & \\
Cladocerans & $0-36,900$ \\
$\quad$ Ceriodaphnia cornuta Sars 1886 & $0-16,573$ \\
Moina minuta (Hansen, 1899) & $0-11,400$ \\
Bosmina hagmanni Stingelin, 1904 & $0-17,700$ \\
Ceriodaphnia silvestrii Daday, 1902 & \\
Copepods & $0-13,200$ \\
Notodiaptomus amazonicus (Wright, 1935) & $0-3,300$ \\
Thermocyclops decipiens Kiefer, 1929 & \\
\hline
\end{tabular}
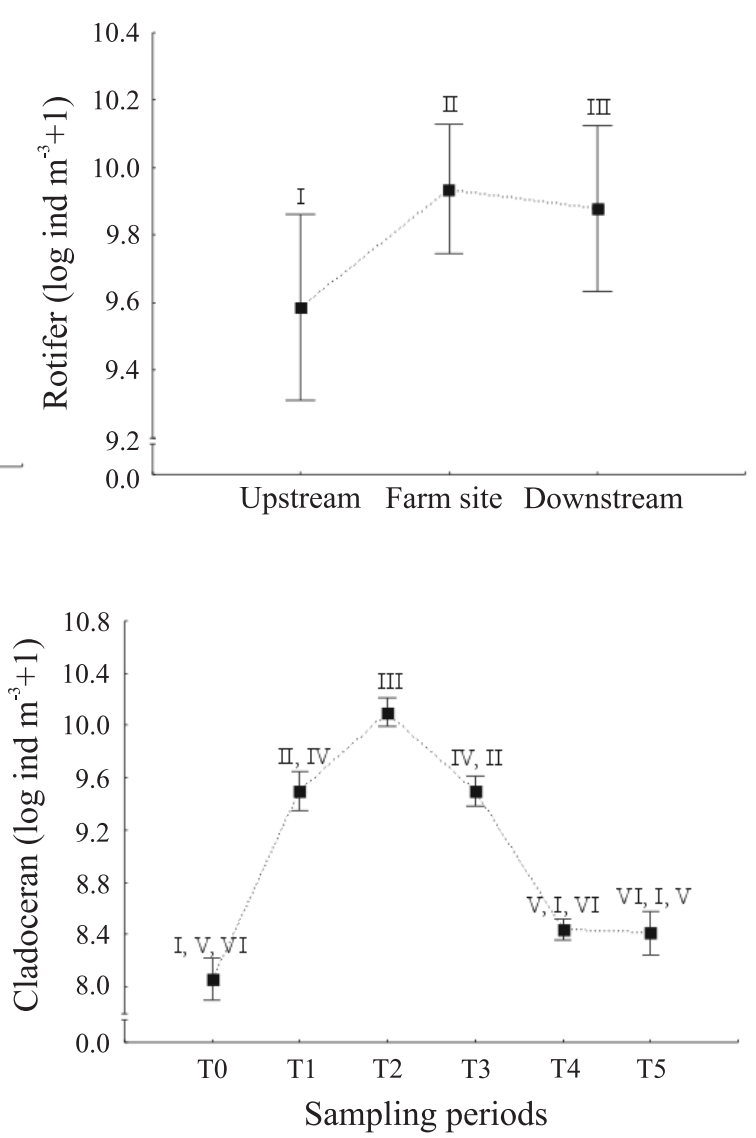

Figure 7. Comparison of mean abundance of total zooplankton, rotifers and cladocerans among different sampling periods and mean abundance of rotifers among different regions, in Guairacá river, Rosana reservoir, Paranapanema river, southern Brazil, according to ANOVA results and Tukey's test. The numbers (I, II, III, IV, V, VI) indicate significant differences through Tukey's test (p<0.05). 
The other variables revealed smaller contribution (partial correlation for abundance of phytoplankton $=0.25$ ). The following model was obtained: Zooplankton=9.83792 + 0.20762 (PCA 1) -0.21128 (PCA 2) + 0.24412 (phytoplankton).

The second model showed that rotifer abundance was influenced by scores derived from PCA 2 and abundance of heterotrophic flagellates and phytoplankton (adjusted $\mathrm{R}^{2}=0.46$ ). Rotifer abundance was negatively correlated with PCA 2 and positively correlated with the abundance of heterotrophic flagellates and phytoplankton. The most important variables for the model were PCA 2 scores (partial correlation $=-0.57$ ) and abundance of phytoplankton (partial correlation $=0.23$ ), while abundance of heterotrophic flagellates revealed a smaller contribution (partial correlation $=0.20$ ). The proposed model was: Rotifers $=1.32372-0.58072$ $($ PCA 2$)+0.20546$ (heterotrophic flagellates $)+0.43638$ (phytoplankton).

This analysis was not performed for cladoceran and copepod abundance since the assumptions of multiple linear regression were not reached.

\section{DISCUSSION}

Zooplankton abundance was high upstream (reference site), low near farm site, and tended to increase downstream. These results suggested the impact of the fish farming on the structure of this community. Otherwise, Demir et al. (2001) observed high zooplankton abundances near cage-culture and low abundances upstream in a Turkish reservoir. Their study showed high values of ammonia, nitrate and phosphate near to the net cages, which was not observed in our study.

The spatial variation in zooplankton abundance was defined by microcrustacean abundance. Copepods, mainly calanoid, presented high abundances upstream (reference site) and low downstream. These indicated an impact of the fish farming on the copepods abundance as observed to the zooplankton abundance. Copepods calanoids can feed on bacteria, small food particles and algae $(20 \mu \mathrm{m})($ MATSUMURA-TUNDISI $\&$ TUNDISI, 2005) and the bacteria and phytoplankton communities showed a similar spatial variation of these copepods.

Cladoceran abundance also contributed to the spatial zooplankton abundance variation. These microcrustaceans presented high abundance in the reference site (upstream) and low near the farm site and downstream, as observed by SANTOS et al. (2009) in the Furnas hydroelectric reservoir (state of Minas Gerais, Brazil). The authors attributed these results to the impact of fish farming. Guo \& Li (2003) found different results in a Chinese reservoir, where these microcrustaceans presented high biomass near net cages, and related to the nitrogen and phosphorus influence at the net cages, as observed by DEMIR et al. (2001). These influences were not verified in our study.

Rotifers also contributed to the zooplankton spatial abundance variation, mainly downstream from farm site. This group presented high abundance in this stretch and near the farm site, as shown by the ANOVA and Tukey's test results. In this way, the fish farming appeared to favor the rotifer population growth. Studies carried out by GuO \& Li (2003) also showed high abundance of these organisms near cage-culture, and related these results to increases in nutrient concentrations. This influence was not verified in our study.

Otherwise, the spatial abundance variation of rotifer was related to the spatial abundance variation of the heterotrophic flagellates (PEREIRA, 2008) and phytoplankton, mainly Cryptophyceae (Borges et al., 2010). According to ARNDT (1993), rotifers can feed on bacteria, heterotrophic flagellates and small ciliates. NogueIRA (2001) added that rotifer is the most abundant smaller filtering group in freshwater environments due their capacity to ingest smaller food particles, as also showed by LANSAC-TÔHA et al. (2005) in tropical reservoirs. The regression model evidenced a significant and direct relationship between rotifer abundance and heterotrophic flagellate (partial correlation $=0.20$ ) and phytoplankton abundances (partial correlation $=0.23$ ) Some studies stated the importance of heterotrophic flagellates as food resources for the rotifers (PATERSON et al., 1997; AuER et al., 2004).

The physical and chemical variables showed a clear temporal variation which could characterize the experimental area. The PCA 1 scores, which explained the greater limnological variation $(36.08 \%)$, showed a sampling group with the beginning of the cage-culture $\left(15^{\text {th }}\right.$ and $30^{\text {th }}$ sampling days) and a group with others days. These results suggested a high primary production in the beginning (high values of $\mathrm{pH}$, turbidity and low values of dissolved nitrogen and phosphorus). It was observed a positive significant relationship between zooplankton abundance and PCA 1 scores probably due to the increased primary production.

According to the distribution of PCA 2 scores, it was possible to distinguish the reference sampling time (T0) and the last sampling day $\left(120^{\text {th }}\right.$ sampling day $)$. The PCA groups were distinguished by higher nutrients concentration and low values of dissolved oxygen in the reference time and in opposite in the end. Phytoplankton abundance increased 15 days after the reference time (BorGEs et al., 2010), when the nutrients decreased. At this time the rotifers abundance increased and it was observed a negative significant relationship between these organisms and the nutrients concentration (PCA $2)$, which were used to the primary production.

The temporal variation in zooplankton abundance increased according to the increased primary production at 15 days after the beginning of the experiment (T1). This high abundance was due to the contribution of rotifers and cyclopoids (young and adults) and young calanoids. A peak of zooplankton, mainly rotifer abundance, observed on the $15^{\text {th }}$ day was coincident with an increase in the phytoplankton, mainly Cryptophyceae, and heterotrophic flagellates abundance (PEREIRA, 2008; Borges et al., 2010). The relationship between these groups has been discussed in the literature (ARNDT, 1993; PATERSOn et al., 1997; AuER et al., 2004), and in the present study, a significant relationship was evidenced by the regression analysis.

The community permanence in the area was related to the cladoceran and adult calanoid numerical contribution, although in low abundances. At this time, Cyanobacteria were dominant in phytoplankton 
community (Borges et al., 2010). Several studies have also verified the negative effect of Cyanobacteria on the zooplankton community (HANEY, 1987; LAMPERT, 1987; DeMott, 1999; Ghadounani et al., 2003; Leflaive \& TenHAGE, 2007). Thus, the maintenance of zooplankton abundance during the Cyanobacteria bloom indicates that the community must have used other food resources, such as bacteria and heterotrophic flagellates. STARKWEATHER $e t$ al. (1979) and Melão (1999) stated that bacteria and nanoflagellates are important alternative food resources to rotifers in reservoirs. Although, the relationship between the abundances of these food resources and microcrustaceans was not analyzed due to the assumptions of multiple linear regression were not reached.

At the end of the experiment, zooplankton abundance was again best represented by rotifers, when phytoplankton and heterotrophic flagellate abundance also increased. Borges et al. (2010) showed again an increased of the Crytophyceae at this time. This result was also made apparent by the regression analysis. A direct and significant relationship between zooplankton abundance and phytoplankton abundance (partial correlation $=0.25$ ) was observed, as highlighted by Tukey's test showing differences in zooplankton abundance over time.

Another relationship observed in terms of community structure was the decrease in rotifer abundance at the same time as a peak in cladoceran abundance, indicating a competition between these groups, mainly by Cryptophyceae (BORGEs et al., 2010). In this period, cladocerans were more abundant than rotifers, due to the great abundance of small-sized cladocerans such as Ceriodaphnia cornuta Sars, 1886 and Bosmina hagmanni Stingelin, 1904. BRooks \& Dodson (1965) suggested that filter-feeding zooplankton compete for a similar size of food $(1-15 \mu \mathrm{m})$ (the size sizeefficiency hypothesis) and GILBERT (1988) added that the size structure of cladocerans can control rotifer dominance in aquatic communities.

Our hypothesis was partially rejected because zooplankton was abundant at the reference site. Only rotifers showed higher abundance near the cage-culture due to the influence of the food availability. But, the dynamic of the community during the experiment was also related to the food availability. The results suggested the impact of the fish farming on the zooplankton community. This was pointed by the rotifers answers to the changes on the food availability and by the competition among the zooplankton groups. This biotic interaction influenced the structure of the community.

The spatial and temporal variation of the physical and chemical variables presented an indirect relationship to the structure and dynamic of the zooplankton community because this variation indicated the primary production in the environment.

Acknowledgments. The authors are grateful to $\mathrm{CNPq}$ (Pronex) for financial support, to Nupelia (UEM) for logistical support, to Dra Lucia Sipaúba Tavares, Dr. Fábio Amodêo LansacTôha and Dr. Nadson Ressye Simões for suggestions, to Dr. Luiz Felipe Machado Velho and Dra. Sueli Train for data assistance, to CAPES and $\mathrm{CNPq}$ for the scholarships and productivity fellowships for CCB.

\section{REFERENCES}

Abery, N. W.; Sukadi, F.; Budhiman, A. A.; Kartamihardua, E. S.; Koeshendrajana, S. \& Silva, S. S. 2005. Fisheries and cage culture of three reservoirs in west Java, Indonésia; a case study of ambitious development and resulting interactions. Fisheries Management, and Ecology 12:315-330.

Alves, R. C. P. \& Baccarin, A. E. 2005. Efeito da produção de peixes em tanques-rede sobre sedimentação de material em suspensão e de nutrientes no córrego da Arribata (UHE Nova Avanhandava, Baixo Rio Tiete, SP). In: Nogueira, M. G.; Henry, R. \& Jorcin, A. eds. Ecologia de reservatórios: impactos potenciais, ações de manejo e sistemas em cascata. São Carlos, Rima. p.349-377.

ARndT, H. 1993. Rotifers as predators on components of the microbial web (bacteria, heterotrophic flagellates, ciliates) a review. Hydrobiologia 255/256:231-246.

Auer, B.; Elzer, U. \& ARndt, H. 2004. Comparison of pelagic food webs in lakes along a trophic gradient and with seasonal aspects: influence of resource and predation. Journal of Plankton Research 26:697-709.

Borges , P. A. F.; Train, S.; Dias, J. D. \& Bonecker, C. B. 2010. Effects of fish farming on plankton structure in a Brazilian tropical reservoir. Hydrobiologia 649:279-291.

Bottrell, H. H.; Duncan, A.; Gliwicz, Z. M.; Grygierek, E.; Herzig, A.; Hillbricht-Ilkowska, A.; Kurasawa, H.; Larsson, P. \& Weglenska, T. 1976. A review of some problems in zooplankton production studies. Norwegian Journal of Zoology 24:419-456.

Brooks, J. \& Dodson, S. 1965. Predation, body size, and composition of plankton. Science 150:28-35.

Carmouze, J. P. 1994. O metabolismo dos ecossistemas aquáticos: fundamentos teóricos, métodos de estudo e análises químicas. São Paulo, Edgard Blüncher/SBL. 253p.

CESP (Companhia Energética de São Paulo). 1998. Conservação e manejo nos reservatórios: limnologia, ictiologia e pesca. São Paulo, Série Divulgação e Informação. 166p.

Demir, N.; Kirkagac, M. U.; Pulatsu, S. \& Bekcan, S. 2001. Influence of trout cage on water quality, plankton and benthos in an Anatolian Dam Lake. The Israeli Journal of Aquaculture-Bamidgeh 53:115-127.

DeMotT, W. R. 1999. Foraging strategies and growth inhibition in five daphnids feeding on mixture of a toxic cyanobacterium and green alga. Freshwater Biology 42:263-274.

Ghadouani, A.; Pinel-Alloul, B. \& Prepas, E. E. 2003. Effects of experimentally induced cyanobacterial blooms on crustacean zooplankton communities. Freshwater Biology 48:363-381.

Gilbert, J. J. 1988. Suppression of rotifer populations by Daphnia: a review of the evidence, the mechanisms and the effects on zooplankton community structure. Limnology and Oceanography 33:1286-1303.

Giné, M. F.; Bergamin, F.; Zagatto, E. A. G. \& Reis, B. F. 1980. Simultaneous determination of nitrate and nitrite by flow injection analysis. Analytica Chimica Acta 114:191-197.

Guo, L. \& Li, Z. 2003. Effects of nitrogen and phosphorus from fish cage-culture on the communities of a shallow lake in middle Yangtze river basin of China. Aquaculture 226:201-212.

HaKanson, L. 2005. Changes to lake ecosystem structure resulting from fish cage farm emissions. Lake and reservoir Management 10:71-80.

HANEY, J. F. 1987. Field studies on zooplankton-cyanobacteria interactions. New Zealand Journal of Marine and Freshwater Research 21:467-475.

JACKSON, D. A. 1993. Stopping rules in principal component analysis - a comparison of heuristic and statistical approaches. Ecology 74:2204-2214.

JiWyam, W. \& ChareOnTESPRAsit, N. 2001. Cage culture of Nile Tilapia and loadings in a freshwater reservoir in Northeast Thailand. Pakistan Journal of Biological Sciences 4:614-617.

LAMPERT, W. 1987. Laboratory studies on zooplanktoncyanobacteria interactions. New Zealand Journal of Marine and Freshwater Research 21:483-490.

Lansac-Tôha, F. A.; Bonecker, C. C. \& Velho, L. F. M. 2005. Estrutura da comunidade zooplânctonica em reservatórios In: Rodrigues, L.; Thomaz, S. M.; Agostinho, A. A. \& Gomes, L. 
C. eds. Biocenoses em reservatórios: padrões espaciais e temporais. São Carlos, Rima. p.115-127.

Leflaive, J. \& Ten-Hage, L. 2007. Algal and cyanobacterial secondary metabolites in freshwaters: a comparison of allelopathic compounds and toxins. Freshwater Biology 52:199-214.

Mackereth, F. J. H.; Heron, J. \& Talling, J. F. 1978. Water analysis: some revised methods for limnologists. (Freshwater Biological Association Science Publication, 36). Kendal, Titus Wilson and Sons. 117p.

Matsumura-Tundisi, T. \& Tundisi, J. G. 2005. Plankton richness in eutrophic reservoir (Barra Bonita reservoir, SP, Brazil). Hydrobiologia 542:367-378.

McCune, B. \& Mefford, M. J. 1999. PC-ORD. Multivariate analysis of ecological data (Version 4.01). Oregon, MJM Software Design. 237p.

Melão, M. G. G. 1999. A produtividade secundária do zooplâncton: Métodos, implicações e um estudo na Lagoa Dourada. In: Henry, R. ed. Ecologia de Reservatórios: estrutura, função e aspectos sociais. Botucatu, Fundibio/Fapesp. p.149-184.

Neofitou, N. \& Klaoudatos, S. 2008. Effect of fish farming on the water column nutrient concentration in a semi-enclosed gulf of the Eastern Mediterranean. Aquaculture Research 39:482-490.

Nogueira, M. G. 2001. Zooplankton composition, dominance and abundance as indicators of environmental compartmentalization in Jurumirim reservoir. Hydrobiologia 455:1-18.

Paterson, M. J.; Findlay, D.; Baety, K.; Schindler, E. U. \& McCullough, G. 1997. Changes in the planktonic food web of a new experimental reservoir. Canadian Journal of Fisheries and Aquatic Sciences 54:1088-1102.

Pereira, D. G. 2008. Estrutura e dinâmica da abundância de bactérias, protozoários flagelados e ciliados planctônicos: respostas ao cultivo de peixes em tanques-rede. $38 \mathrm{p}$. Tese (Doutorado). Universidade Estadual de Maringá, Maringá. (Unpublished)

Santos, R. M.; Rocha, G. S.; Rocha, O. \& Wisniewski, M. J. S. 2009. Influence of net cage fish cultures on the diversity of the zooplankton community in the Furnas hydroelectric reservoir, Areado, MG, Brazil. Aquaculture Research 40:1-9.

Schimitтou, H. R. 1993. High density fish culture in low volume cages. Cingapura, American Soybean Association. 78p.

Sherr, E. B. \& Sherr, B. F. 1993. Preservation and storage of samples for enumeration of heterotrophic protists. In: KEMP, P.; Sherr, B. F.; Sherr, E. B. \& Cole, J. eds. Current Methods in Aquatic Microbial Ecology. New York, Lewis Publishers. p. 207-212

Sokal, R. R. \& Rohlf, F. J. 1991. Biometry: the principles and practice of statistics in biological research. New York, W.H. Freeman and Company. 859p.

Starkweather, P. L.; Gilbert, J. J. \& Frost, T. M. 1979. Bacterial feeding by the rotifer Brachionus calyciflorus: clearance and ingestion rates, behavior and population dynamics. Oecologia 44:26-30.

StatsofT. 2005. Statistica for Windows. (Version 7.1). USA, Statsoft Inc., Tulsa.

UTERMÖHL, H. 1958. Zur Vervollkommnung der quantitativen Phytoplankton-Methodik. Mitteilungen Internationale Vereinigung für Theoretische und Angewandte Limnologie 19:1-38.

YiYong, Z.; JiAnoIU, L.; YongoIng, F. \& Min, Z. 2001. Kinetics of alkaline phosphatase in lake sediment associated with cage culture of Oreochromis niloticus. Aquaculture 203:23-32. 